This is an electronic reprint of the original article. This reprint may differ from the original in pagination and typographic detail.

Author(s): Mykkänen, Johanna; Eerola, Petteri; Forsberg, Hannele; Autonen-Vaaraniemi, Leena

Title: $\quad$ Fathers' narratives on support and agency : a case study of fathers in a Finnish child welfare NGO

Year: $\quad 2017$

Version:

Please cite the original version:

Mykkänen, J., Eerola, P., Forsberg, H., \& Autonen-Vaaraniemi, L. (2017). Fathers' narratives on support and agency : a case study of fathers in a Finnish child welfare NGO. Nordic Social Work Research, 7(3), 236-248.

https://doi.org/10.1080/2156857X.2017.1356350

All material supplied via JYX is protected by copyright and other intellectual property rights, and duplication or sale of all or part of any of the repository collections is not permitted, except that material may be duplicated by you for your research use or educational purposes in electronic or print form. You must obtain permission for any other use. Electronic or print copies may not be offered, whether for sale or otherwise to anyone who is not an authorised user. 


\title{
Fathers' narratives on support and agency: A case study of fathers in a Finnish child welfare NGO $^{1}$
}

\author{
Johanna Mykkänen, PhD, University of Jyväskylä \\ Petteri Eerola, PhD, University of Tampere \\ Hannele Forsberg, PhD, University of Tampere \\ Leena Autonen-Vaaraniemi, PhD, University of Tampere
}

\section{Introduction}

Across the Nordic countries, caring and active fatherhood and the engagement of fathers in equally shared parenthood are ideas widely supported by legislation, family policies and parental everyday life practices (Coltrane and Behnke 2013; Goldscheider, Bernhardt and Lappegård 2014; Almqvist 2008; Björnberg 1998). Thus, these societies are commonly cited as forerunners in promoting and implementing caring fatherhood (e.g. Walmsley and Tessier 2015). The Nordic ideal of shared parenting has also been noted internationally, probably as a result of findings by researchers indicating that father involvement benefits the wellbeing of children, mothers and fathers themselves (Flouri 2005; Lamb 2010). Unfortunately, this glittering picture of Nordic fatherhood does not tell the whole story. Alongside these Nordic forerunners of sharing and caring fathers are a group of fathers who, e.g., behave aggressively, have serious mental health and substance-abuse problems and can be a danger to their partner and their children (e.g. Eriksson, Hester, Keskinen and Pringle 2005). Although these fathers are commonly encountered by child welfare and social workers, with a few exceptions (e.g. Bangura Arvidsson 2003; Storhaug 2013; Eriksson, Bruno and Näsman 2013) they have somewhat been neglected by the Nordic fatherhood and child welfare research community. For example, they are not included in the latest edited volume on Nordic fatherhood (Eydal and Rostgaard 2015; see also Bäck-Wiklund 2015). Studies on men and masculinities have also paid little attention to encounters with men in child welfare services (henceforth child welfare).

Although both fatherhood and child welfare research have increased significantly over the past two decades across the Nordic countries, including Finland, little research interest has been shown in fathers as clients of child welfare services. Thus, a clear need exists to further knowledge on this issue, and not only in the Nordic context but also internationally. Several scholars have pointed to the fact that the research on parental support practices and child maltreatment has focused on mothers (Lam et al 2009; Shafer and Wendt 2015; Cameron, Coady and Hoy 2014). Researchers have also called for studies on, among others, best practices for engaging fathers in caring parenting, father's subjective barriers to fathering, and fathers' needs for and experiences of support received from child welfare services (Coady et al 2014; Hautanen 2005, 67; Lam et al 2009; Lee et al 2009; Lundahl, Tollefson, Risser and Lovejoy 2008). However, the lack of knowledge, especially in the Nordic context, is striking, as both

\footnotetext{
${ }^{1}$ The first and second author have contributed equally and thus share the first authorship of the article.
} 
fatherhood and child welfare have been hot topics politically in the Nordic countries for years. In Finland, for instance, the strengthening of fathers' involvement in the development of child welfare has recently been called for by the Finnish National Institute for Health and Welfare (Perälä et al. 2012, 13). Investment in wellbeing and health, including the development of child and family services, has also been highlighted as a strategic priority by the current Finnish government. In addition, the wellbeing and positioning of men in their encounters with social services has attracted considerable media attention in Finland during recent years, as shown by the number of reports in Helsingin Sanomat, the most widely read Finnish daily.

In this article, we examine the narratives of fathers who have sought and received support from a Finnish nation-wide child welfare $\mathrm{NGO}^{2}$. The question is asked: What narratives on seeking and receiving support and on their agency do fathers produce? The article proceeds as follows: First, we look at fathers and fatherhood in the context of child welfare, with special focus on the theme of support. We then introduce the methods and data of the study. Here, we also familiarize the reader with the concept of agency. Finally, we present our findings and draw conclusions.

\section{Fathers in child welfare: Lessons from the recent research}

In recent years, the mainstream of both Nordic and international fatherhood research has focused mainly on middle-class fathers living in hetero-normative settings, i.e., male parents commonly referred as the "new" fathers in the research literature (e.g. McGill 2014; Marks and Palkovitz 2004; LaRossa 1997). According to the Norwegian researchers Söderström and Skårderud (2013), this has led to a situation in which fathers with various problems in life management have become neglected. This has been particularly evident in Finland, where issues such as fathers' share of child care (Miettinen and Rotkirch 2012), time spent by fathers with their children and their parental practices (Halme 2009), and fathers' narratives of becoming and being a father (Mykkänen 2010; Eerola and Huttunen 2011; Eerola 2014) have been commonly studied. One possible explanation for the focus on middle-class fathers might lie in the Nordic culture. In Finland, the public discussion on fathers tends to be heavily focused on the father's role in early child care and their take-up of parental leave, as it is assumed that, at least on some level, fathers share child care with the mothers of their children. For example, according to a recent time-use study, the gap between mothers' and fathers' share in childcare has narrowed considerably since the late 1980s (Miettinen and Rotkirch 2012; Ylikännö, Pääkkönen and Hakovirta 2014).

Despite the narrow focus of the existing research, some steps towards giving a more complex picture of Finnish fatherhood have been taken. For instance, studies have been conducted on, e.g., drinking fathers and their sons (Pirskanen 2011; see also Pirskanen 2015), fathers with

\footnotetext{
${ }^{2}$ In Finland, our case example of a Nordic welfare state, child welfare services are understood broadly; they refer on the one hand to universal welfare benefits and services available to all families with children, and on the other to child- and family-specific child welfare work implemented on the municipal level and by, e.g., NGOs. The most typical reasons for the need of the latter are family members' mental health issues or problems with alcohol or substance abuse.
} 
violent behaviour (Nyqvist 2001; Forsberg 2005; Keskinen 2005) and post-divorce fatherhood (Autonen-Vaaraniemi 2010; Forsberg and Pösö 2008). Aalto (2012), in turn, investigated how fatherhood has been portrayed historically and what conceptions of fatherhood informed public debates on fatherhood in the 1990s. Fatherhood as a gendered form of parenting has also received attention in studies on fathers in the context of expert discussions (Vuori 2009), violent fatherhood (Hautanen 2002) and parental violence as revealed in custody documents (Hiitola 2011). Some research has also been conducted on male-specific social services, such as work with violent men (see also Keskinen 2008), crisis work with men or support groups for divorced men (Nyqvist 2006).

Internationally, there has recently been a strengthening of the research interest on fatherhood in child welfare. One of the main findings is that fathers are often treated as if they were invisible in child welfare work (Brown, Callahan, Strega, Walmsley and Domitelli 2009), the implication being that fathers are not considered to be as significant as protectors and providers of adequate care for their children as mothers (Hautanen 2005, 73). It has been claimed that adherence to traditional masculine ideals causes the welfare system to underestimate and ignore men, and that this may even exacerbate negative responses in male clients, such as substance abuse and aggressive behaviour (e.g. Valkonen and Lindfors 2012). Thus, ignoring fathers in child welfare may have harmful consequences for the welfare of both fathers and their families, possibly adding further to the heavy burden already borne by mothers and eroding the child's relationship to his or her father (Featherstone 2004).

If, based on the recent international research on the intersection of fatherhood and child welfare, we try to construct the "bigger picture", two topics immediately come to the fore: alcohol/substance abuse and violence (including sexual violence). In several studies, these themes appear side by side. For example, it has been demonstrated that fathers' substance abuse or violence have negative effects on their children and spouses (Arenas and Greif, 2000) and that fathers with substance addiction cannot be trusted to provide a safe, sensitive and supportive environment for a child (Söderström and Skårderud 2013). Several studies have also shown how alcohol/substance abuse undermines a parent's caregiving competence and increases the likelihood of a serious threat to their children's development and health (Andreas, O'Farrell, and Fals-Stewart, 2006; Lee, Bellamy and Guterman 2009; Söderström and Skårderud 2013).

Research has also revealed that men are quite often reluctant to seek emotional or psychological support, mainly due to masculine norms emphasizing the importance of self-sufficiency, strength, and invulnerability (Call and Shafer 2015; Vogel and Heimerdinger-Edwards, Hammer and Hubbard 2011). However, promising results have been reported by studies on various programs and work targeted to fathers in need of support. It has been noted that a positive attitude towards a father by his welfare services practitioner promotes the father's engagement with his child (Ashley et al. 2006; Bayley et al. 2009; English et al. 2009). According to one study, male workers and father-specific child welfare services had a particularly prominent impact on fathers' engagement (Bayley et al. 2009). Violent fathers form a group that is even more reluctant to seek or receive help than those experiencing other kinds of problems. Such fathers present a serious challenge for child welfare services (Featherstone 2013; Maxwell et al. 2012, 168; Hearn and Pringle 2006, 367-368; Scourfield 2001; see also 
Lee, Bellamy \& Guterman 2009). On a more positive note, however, a recent UK study (Stanley, Graham-Kevan and Borthwick 2012) describes how a voluntary program for male perpetrators of domestic violence promoted fathers' motivation to "be a better father" and their further involvement in social services. To conclude, the father in child welfare services is a somewhat ambiguous figure, ranging between an invisible person and a problem-creator. However, the father as a potential resolver of welfare problems seems to be less familiar.

\section{Narrative research process}

The study presented in this article was implemented in a narrative framework. Since "the narrative turn" in the 1980s, narrative methods have been broadly applied to further understanding of how people experience, live, and talk about sensitive life experiences (e.g. Hänninen 2004; Riessman 2003). The basic premise of narrativity is that telling stories is an innate and familiar way by which people produce meanings and perceive the world. Moreover, since personal experiences and stories interact with cultural narratives, narrative inquiry is interested in how people narrate their lives and how their narratives are connected to the wider social context. (Plummer, 2001; Somers, 1994.) Among the topics studied using a narrative approach, intimate topics such as life stories and life changes have been especially popular (e.g., Hänninen, 2004; Riessman, 2003). For instance, studying life changes as narratives enables us to capture the meanings people give to the most sensitive experiences in their lives (Hänninen, 2004). In this article, we studied fathers' narratives on the topic of support in relation to agency. Concept of agency has been argued to be elusive (Hitlin and Elder 2007), but according to our understanding, it refers to the intentional actions and choices that individuals take within the opportunities and constraints of history and social circumstances (Elder, Johnston and Crosnoe 2003; Giddens 1991).

The analysis reported in this article is based on interviews conducted in autumn and spring 2015-2016 with client fathers of the Federation of Mother and Child Homes and Shelters ${ }^{3}$ (FMCHS; in Finnish Ensi-ja turvakotien liitto). FMCHS is one of the largest national child welfare NGOs in Finland that help children and families in difficult and insecure life situations. For example, the FMCHS supports families by empowering parents in ways that are both concrete (e.g., helping them in household duties) and psychological (e.g., helping them to find their particular strengths as parents amidst their problems). The FMCHS also works towards preventing and putting an end to domestic violence by helping both victims and perpetrators. Although most of the work done by the FMCHS is open to anyone regardless of gender, it also offers some gender-sensitive services, such as father-groups and assistance targeted to men of all ages who are experiencing difficulties in life management. In 2014, a total of 2999 men sought help through the male-specific services offered by the FMCHS (Federation of Mother and Child Homes and Shelters, 2014). In the male-specific

\footnotetext{
${ }^{3}$ The FMCHS was established in 1945, primarily to help young mothers in difficult life situations. For several decades it has operated as general child welfare NGO, working and supporting all family members irrespective of age or gender. Finnish name of the FMCHS does not include the gender of the parent.
} 
services offered by the FMCHS, both men and women practitioners work with men and fathers.

In total, 16 fathers (aged 24-50 years) with diverse backgrounds were interviewed for the study. All the fathers had encountered various difficulties in life management and many had experienced significant problems such as substance abuse, violence, mental problems, personality disorders and various difficulties in the spousal relationship and raising their child. In several cases, their spouses had also experienced similar challenges. The fathers participated in the services on a voluntary basis, although, e.g. due to various other problems, many had been directed to the FMCHS's support services by their municipal child welfare authorities. At the time of the interviews, all the fathers had been participating in these services for several months, and most of them were no longer living through the worst phases of their crises.

Most of the fathers (10) had a vocational education, three had a BA or MA degree and three had exited education after completing secondary school. Eleven fathers were working full time, three were unemployed, one was a student and one was a stay-at-home father. As Finnish society is still ethnically rather homogeneous, all but one of the interviewed men were white native Finns. The fathers had from one to five children (from 1 month to 26 years) and 12 of them were living together with the mother of their child(ren). Thirteen of the fathers had joint custody with the child's mother and one of them had single custody. Two of the fathers did not have legal custody. All the interviewed men shared a strong paternal identity, though not all them were the biological fathers of their children.

A distinctive feature of the data is that the interviews were not conducted by the researchers themselves, but by family practitioners working for the FMCHS, with pre-selected themes and topics developed by the researchers. Fathers were also recruited by their assigned practitioner in the FMCHS. This procedure could be regarded as ethically dubious, and for good reason. For instance, it might be easier for a client to agree to an interview with an interviewer who is familiar and trustworthy. Equally, it might - for the same reason - be harder to refuse the invitation to be interviewed. Clients might also find it disagreeable or annoying to be invited for interview by their practitioner. Clients might also ponder whether a refusal to be interviewed will affect the client-practitioner relationship in the future. These issues were dealt with by giving the practitioners involved clear instructions on how to recruit fathers for the interviews. First, fathers were given a comprehensive description of the study both orally and in writing. At this point, the voluntariness of participation was clearly stressed. Fathers were asked to take time to think carefully about whether they would like to participate or not, and give their decision at the next meeting. To prepare the practitionerinterviewers for the interviews, they were offered training on how to conduct research interviews on sensitive topics. The interviewers were asked to remind fathers before stating the interview that this was not a treatment or therapy session, but a research interview that they can call off at any time. The practitioner-interviewers were tutored in how to encourage the fathers to highlight the matters they considered important. At the same time, they were instructed to make sure that the fathers were aware that in the interviews they were free to tell 
as much or as little as they wished, and that if they preferred not to talk about a specific issue, then their wish would be respected.

This study was carried out in compliance with the ethical guidelines for the responsible conduct of research issued by the Finnish Advisory Board on Research Integrity (Finnish Advisory Board on Research Integrity 2012). Before gathering the interviews, research permissions were obtained from the central office of the FMCHS. All the names are pseudonyms, while in the results section we refer to all the individual children simply as "the child". All but one of the fathers' interviews were conducted in Finnish, so the narrative samples presented have been translated into English with the aim of extracting the general sense and meanings of the narratives rather than producing a literal word-for-word translation (see Nikander 2008).

The first step of the analysis was to read all the interview transcripts several times. Our main principle was to let the data "speak for itself" as much as possible. We aimed to identify the narratives on support produced by the interviewed fathers by writing summaries of all the interviews. To stay close to the original data and retain its authenticity, we used the fathers' utterances verbatim in our summaries as far as possible. By constructing the summaries, we obtained a picture of how different life events in the past, present and future were connected, and what kinds of turning points or life changes (see McAdams, Josselson and Lieblich 2001) were contained in the transcripts. As the fathers appeared to produce very divergent narratives on their ability to act and make decisions, we decided to focus on the issues of seeking and receiving support in difficult life situations specifically from the perspective of agency.

\section{Narratives on support and agency}

We identified four narratives from the data. We labeled these as the hero (increasing agency), the victim (decreasing agency), the outsider (stable agency) and the fortunate (stable agency) narrative. To introduce each narrative, we have constructed composite narratives that include excerpts from interviews and elements gathered from several interviewees.

\section{Narrative 1: "The hero" (increasing agency)}

My previous life was like 'use or die'. Sometimes I just felt that my head's gonna explode, really. I was so tired and disappointed with myself, I somehow escaped my problems and responsibilities by using narcotics. But the fact that I've had the possibility to call my practitioner (at the FMCHS) no matter what time of the day it is, this has brought so much light and safety to my life. The knowledge that everything will be fine and things will work out, it's been so important, you know. Becoming a father has been a salvation and a chance to grow up. It's been a rocky road, as we know there's no golden rule for these things. But now I'm really proud of myself. I made it! (A composite constructed from the discourse of several interviewees) 
The hero narrative, depicting a father's increasing agency, is about going through major challenges and difficulties in life, and in the end, experiencing feelings of trust, joy and gratitude. The narrative concludes with the recognition of empowerment after survival, which has been preceded by various insecurities and struggles. Turning points away from dead ends had been found by the fathers; for example, in the case of substance abuse, it was either continue using or stop using and seek and receive support, as there is no in-between stage. This narrative underlines the father as the "hero of his own life".

According to the interviews with the fathers with the hero narrative, they sought and received support from various directions: from day care centers, Alcoholics Anonymous (AA) and Narcotics Anonymous (NA) groups, detoxification centers, peer-groups, child welfare clinics, hospitals and NGOs such as the FMCHS. The fathers emphasized how support and guidance in everyday life (e.g. help with child care and knowledge on parent-child interaction), quite often provided by the FMCHS, was especially valued. According to Kalle (age 32): "I've learnt so much new... Like, you know, the ways, the basics of human interaction... In our daily life, I think that I can now act, behave and look after kids much more reasonably than before".

The interviews implied how practices that were tailored especially to the fathers' needs seemed to have crucial role in their recovery process. The fathers narrated how, through e.g., counselling, home visits and peer-group meetings, they have learned new ways of dealing with disappointments. These strategies were also mentioned as a source of self-respect. As Sakari (age 24) put it: "This place (FMCHS) has given so much more than I ever expected... I've always got support, and I've got the confidence that I can ask for help if I need it, that I'm worthy of it... Like, I'm not going to be sold down the river ever again".

In their accounts, fathers also emphasized how the support received had brought them courage and confidence as parents, qualities that they felt they were lacking before. This support had also given them hope that they could be good and responsible parents to their children. Pekka (age 47), for example, stated: "This (seeking help from the FMCHS) has mostly been about learning new things, like, how to be bit more merciful to yourself, and how to be a better father.

Many of the interviewed fathers narrated experiences of mental or physical violence either as perpetrators or victims, and the connections between these experiences and the men's former behavior were emphasized in the narrative. For example, Sakari (age 24), who started to drink and use drugs at the age of 13, had been maltreated in his childhood by his own father: "Well, my dad... He drank a lot, there was a lot of violence, he had various women... And I didn't feel safe at all... He was really strict, had ridiculous rules, and I got way too much responsibility when I was too young". However, the narrative also describes how the father has learned new ways of dealing with conflicts. According to Kalle (age 32), for example: "Now I see that when I, or equally my wife, lose our tempers and get mad, it's much smarter to go out for a while and cool down than to stay at home and fight and yell at each other".

\section{Narrative 2: “The victim" (decreasing agency)}


The child's already six years old and all this time we've been trying to get help, but it doesn't happen. The authorities have just twiddled their thumbs. They have been pussy-footing though everyone can see that the child is ill. How can we get the child back on track, when he has these self-destructive thoughts and stuff? I really cried out "help me, my child is falling apart in my hands". I felt so sad, how would he manage at the future? I felt a failure when I saw the child wasn't feeling well and I couldn't help him. Then I was left alone in that situation when the divorce came. I wouldn't get to see my child any more. Ifeel that women would have been coddled more, a man can be side-tracked and then they concentrate on the women. I think they should see that men are also human beings. They don't ask me anything and they don't inform me of anything. I just hope I could be a father to my child. (A composite constructed from the discourse of several interviewees)

As a narrative, "the victim" resembles a tragedy as it highlights the difficult and painful situation in which the individual is constantly living, the accompanying feelings of disappointment and disempowerment, and the giving up of the fight against this situation. In this narrative, in which the fathers' agency erodes over time, fathers portray themselves as victims who have tried to get help for their children and themselves, but without any success.

One of the turning points in the narrative is the failure to get help for the child. In his interview, Lauri (age 37) narrates how “We've tried and tried, but it's the same struggle day after day [...] We just didn't have the tools any more to help him. We've tried everything, good and with bad, and sometimes we've tried really extreme ways. [...] Nothing has helped. He also described how his workplace was the only place where he "got peace of mind", otherwise his time was spent at home with a child who had major problems, and neither Lauri nor his spouse had any ideas about how to help him.

In a few of the interviews of the fathers producing the victim narrative, a court order giving the mother custody of the child was the emphasized as turning point that had led to giving up the struggle. The interviews also emphasized the feelings of helplessness and being left alone that characterized this narrative. For example, Janne (age 37) narrated that "I had to withdraw, so the child had at least some chance of survival. It really hurt". These fathers quite often reported how bitter they felt about the child's mother refusing to let them see the child. For example, Jake (age 36) described himself as a responsible father who is willing to see his child, to pay the agreed alimony and to bear his paternal responsibilities. However, in his narrative the child's mother was characterized as a gatekeeper who was using "oppressive mental violence" keeping child out of his life year after year. He also reported being dismissed by the authorities due to his immigrant background (see also Anis 2012). Janne (age 37) also talked about the mother's supremacy in his joint meetings with the child's mother and the social worker: "If the roles were vice versa, if I'd have done the same (as the mother), I'd have been put in handcuffs ... but because the situation was other way round, it was her not me, they just tolerated and accepted everything". In the victim narrative, the father's role was portrayed as trivial or unimportant in the eyes of the social workers, highlighting these fathers' bitterness over their situation. 


\section{Narrative 3: "The outsider" (stable agency)}

The childcare practitioners sent us to the shelter home. Ifeel that I was under surveillance because of my drinking though I didn't even drink that much - only a few times a week, just like the average Finnish guy. They didn't inform me of anything, and I think that I actually got all the knowledge through my wife. These people don't listen to facts, and they are not interested in my point of view, rather they are just happy to hear only one side of the story. And that's where I think things get fucked up. That time was very irritating and nervewracking. Our family have had help, but we didn't ask for it and in that way it was unnecessary. I think these resources should've been given to those, who really need them. (A composite constructed from the discourse of several interviewees)

The third narrative, sharing similarities with "the victim" narrative, was labelled "the outsider". Both narratives emphasize the father's frustration and dissatisfaction, differ in how the father's agency and the identification of the problem are narrated. As in the victim narrative, the father's agency is narrated as decreasing, but in the outsider narrative it is described as low and unchanging from the outset. In this narrative, the father obeys commands, without actively making any decisions himself. Second, the fathers producing the victim narrative didn't seem to have, or recognize themselves as having, any problem or challenges at all. Instead, they discussed how their wishes hadn't been heard or considered at any point, and that it was this that had led to their feelings of confusion and misunderstanding. The support process or the practitioners' work were not criticized as much in the outsider narrative as they were in the victim narrative, as the core of former lies in the feeling of being an outsider, described as being treated like 'air' in the interaction process.

According to their accounts, both Toni (age 34) and Petri (age 34) felt distrusted by authorities such as social workers. Toni, a former homeless drug addict reported, "If you have been an addict, they think you are always an addict. They were suspicious and thought I'm still a complete junkie and I had to run from one office to another to convince them”. Both these interviewed fathers felt that they were being totally controlled and had no real opportunity to show that they had made a change in their life. According to them, this also led to a situation in which most of the conversations and negotiations were carried out between the mother and the practitioner. This was also supported by Matti (age 36), a drying-out alcoholic, who observed that the practitioners mostly concentrate on the mother, and thus the father can sometimes miss important information.

Petri (age 34), an ex-addict with the outsider narrative, also told about his difficult relations with the authorities. According to him: "I was that close to totally losing it ... Like, no-one believes you at all, and all the authorities are chasing me, it's hell...". Also in general in the victim narrative, the father's interaction with the authorities was constructed as too "strict" and "irritating", and more "compassionate, warm and human" relations were wanted.

\section{Narrative 4: "The fortunate" (stable agency)}


Well, it's definitely been tough for us, life, you know... Like, he (the child) has gone through several medicals and treatments, and he's in a kind of special class in school, as he's retarded compared to the others of his age. So, it's been like fighting your way through all this shit, from one day to the next. But on the another hand, despite some difficulties I still have a close and warm relationship with her (the spouse), and, if anything happens, we talk about it. And also these peer groups with other fathers, these have brought lots of light and help into my life. It has been enlightening to see that I'm not the only one with problems, that there are others too. Whereas earlier I used to let off steam by breaking out the bottle, now it's rather talking with someone. (A composite constructed from the discourse of several interviewees)

The fourth narrative was labeled "the fortunate". This narrative highlights the fathers' reported gratitude and contentment with the support received, despite describing some difficulties in child-raising and problems with their intimate relationships. The fortunate narrative is forward-looking in tone. As Leevi (age 50) put it: "Everything turns out to be okay, eventually". This narrative is to some extent consistent with 'the hero' narrative, as in both trust that support will be available when needed is emphasized. Leevi continues: "When the practitioners came along, we got many good hints and knowledge about how to handle situations with the child. I have also learned that even when you fall down deep, you can get up. You don't have to dig the hole deeper, because you can use ladders and climb up."

The differences with the hero narrative can be seen in the issue of agency, major turning points and the emotions described. While in the fortunate narrative agency remained unchanged a smooth life journey with its ups and downs, the hero's agency was strongly increasing with steeper ups and downs. The fathers producing this narrative described themselves as fortunate, knowing that getting help cannot be taken for granted. One of the major sources of support and help mentioned were peer-group meetings, where they could talk with other parents experiencing similar problems.

Another feature of this narrative was the relatively good relationships the fathers enjoyed with their spouses and the mothers of their children. This was reported by Ari (age 47), in a slightly humorous tone: "We've already tolerated each other for 20 years". Erkki (age 26) also positively narrated his working communication with his child's mother, from whom he received positive feedback and support at moments of helplessness and insecurity. A peer group for fathers, gathering once a week, was also underlined as providing essential support for Erkki's family life and fathering. Erkki said that through this support he had become very proud of his ability to 'manage' more and more successfully with his child: "I have learned step by step that fathering isn't nuclear physics, but patience and peace, repeated thousands of times."

Table 1. Juxtaposition of the narratives on support and agency. (ON SEPARATE FILE)

\section{Discussion}


This article reports an analysis of fathers' narratives on support and agency. The empirical data comprised 16 qualitative interviews with client fathers of a Finnish child welfare NGO and conducted by its practitioners. The fathers' accounts were analyzed as narratives produced in a specific time, situation and context. As only men were studied, the accounts given portray the issue of interest only from the point of view of fathers, and especially those who were willing to participate in the study. This leaves the question, who are the fathers who declined or were unable to participate in the study, and what are their stories? To gain a deeper understanding of the father's role in child welfare, more studies from the viewpoint of marginalized men and from the viewpoints of their children and the children's mothers are needed. The present data analysis yielded four narratives, which we labelled the hero, the victim, the outsider and the fortunate. As the narratives reflect as much about the knowledge, attitudes and beliefs that circulate in contemporary culture as they tell about individuals' personal experiences (Brown and Addington-Hall), the narratives also provide insights on the more inconspicuous side of the contemporary Finnish and Nordic fatherhood.

The first of the narratives, the hero, highlighted the father's increasing agency through the provision of support, and the importance of that support in overcoming the obstacles in his life. It has earlier been documented that many personal and contextual barriers constitute potential obstacles to the development of involved, sensitive and caregiving fatherhood (e.g. Söderström and Skårderud 2013). As underlined in the hero narrative, it seems that services targeted to fathers living with various problems can be one way to promote fathers' trust in themselves and support their readiness for a "new start" and a more balanced future. In the hero narrative, support combined with trust, respect and dignity was perceived as promoting a more meaningful and affectionate father-child relationship and the wellbeing of both the father and the other family members. As Coady et al. (2013) have pointed out, fathers value practitioners who are straightforward, honest, supportive, understanding, non-judgmental and reliable, as was the case of the fathers with the hero narrative. The narrative was also consistent with the results reported by Cameron et al. (2014), who noticed how fathers' concerns for their children provided the motivation to try to make the necessary changes in the lives they were leading.

The victim narrative highlighted a father who had undergone a tragedy and encountered a bitter disappointment either in receiving support or in losing custody of a child. As previous studies on divorced fathers have highlighted (see Autonen-Vaaraniemi 2010), some accounts of the fathers with the victim narrative included substantial hostility towards women, i.e. both the mothers and the women social workers and practitioners. The narrative represents father's agency as declining over time. The outsider narrative, in turn, described the story of a father who saw no problems in his life at all. The fathers in the victim and outsider narratives felt that they were not included as much as they would have liked in decisions relating to their children and thus were frustrated. However, in the outsider narrative, the fathers' agency was low throughout and hence these fathers were not fully aware of the problems they were assumed to have and thus felt they were "a target of control" and hence victimized. A dominant theme among these fathers was the priority accorded the mother, causing them to feel that 
they were the objects of active discrimination because of their gender (see Skårstad Storhauga and Øien 2011).

The last narrative, the fortunate, was characterized by a positive attitude and trust in the future, despite the problems with the child or the spousal relationship. The fathers in this narrative had received help at the right time and place, while appreciating that this is not always the case. In particular, the help of peer groups and a warm relationship with the spouse was highlighted. The agency and the emotional tone of this narrative can be described as stable.

Coady, Hoy and Cameron (2013) have argued that so little is known about men's involvement with family practices and child welfare that it is not possible to know how typical or unique individual experiences are. This is the case also in this article. The reported narratives cannot be generalized as they have been constructed from a small sample of 16 fathers. There may be more types of narratives than the four found here. It is also clear that in the interviews in this study the men chose what to tell; the accounts given here are thus not presented as complete or objectively accurate descriptions. The present fathers were also at different life stages- as reflected in their narratives - and thus the 'point' at issue varies across their narratives, which makes it difficult to compare them. However, this case study is a starting point towards a better understanding of the experiences of fathers receiving support from child welfare services when facing diverse crises in their family life.

In summary, all of the present sample of fathers were willing engaging constructively with their children. As Cameron et al. (2014) have argued, to take advantage of this potential, practitioners need to become more engaged with these men and become more open to fathers' points of view. This is also connected to the broader issue of creating a child and family welfare system that focuses more on providing useful and welcome assistance to children, parents and families in very different life situations and stages. In this article, however, it should be noted that many of the interviewees had been motivated to seek help and make changes in their lives, as they had voluntarily sought help. The fathers in the hero and fortunate narratives had mostly had positive experiences of the male-specific services of the NGO (FMCHS). Despite the negative experiences reported by the fathers in the victim and outsider narratives, our analysis indicates that services directed towards men and fathers can produce important positive outcomes for both the father, and hence probably for the whole family that, according to the men's accounts, often remain unrealized in mainstream municipal child welfare services.

Our assumption is that the secret behind the success of the work directed towards men and fathers lies its ability to provide services and support in which men are encountered as equals and which acknowledges their needs. The situation with respect to the needs and help services described, for example, in the hero and fortunate narratives, where fathers and their family received help, was, in cases where the outcome was not optimal, relieved by help and support from the practitioners. Some of these observations are familiar from earlier research: giving male clients space and a demonstrating a positive attitude towards fatherhood on the part of professionals have been found to raise the level of fathers' participation in child welfare (e.g. Ashley et al. 2006). Interestingly, British social work researcher Brid Featherstone and her 
colleagues (2014) recently called for child protection practices that, instead of focusing on system-driven assessments and interventions, should be developed in the direction of (family) support, with social workers as agents of hope. Greater emphasis should be placed on developing relationship-based work that is sensitive to vulnerable parents' needs. Our empirical case study has shed some light on this issue, and revealed new, positive knowledge on fatherhood obtained in the context of male-specific child welfare services. Whereas previous studies on fatherhood and child welfare have tended to highlight fathers as sources of social problems, we prefer to conclude on a positive note: there are also fathers with social problems who are willing and able to change, if they are taken seriously.

\section{Reference}

Aalto, I. 2012. Isyyden aika. Historia, sukupuoli ja valta 1990-luvun isyyskeskusteluissa. [Era of Fatherhood. History, gender and power in the fatherhood discussion] Nykykulttuurin tutkimuskeskuksen julkaisuja 112. Jyväskylä: Jyväskylän yliopisto.

Almqvist, A-L. 2008. "Why most Swedish fathers and few French fathers use paid parental leave: An exploratory qualitative study of parents.” Fathering 6 (2): 192-200.

Andreas, J. B., O'Farrell, T. J., and Fals-Stewart, W. 2006. "Does individual treatment for alcoholic fathers benefit their children? A longitudinal assessment." Journal of Consulting and Clinical Psychology, 74: 191-198.

Anis, M. 2012. Isäkuvat monikulttuurisissa lastensuojelun kohtaamisissa [Portrays of fatherhood in multicultural encounters in child protection.]. In Monikulttuurisuuden sukupuoli. Kansalaisuus ja erot hyvinvointiyhteiskunnassa [Multicultural gender. Citizenship and distinctions in welfare society], edited by S. Keskinen, J. Vuori and A. Hirsiaho, 321-348. Tampere: Tampere University Press.

Arenas, M. L., and G. L. Greif. 2000. "Issues of fatherhood and recovery for VA substance abuse patients." Journal of Psychoactive Drugs 32: 339-341.

Ashley, C., B. Featherstone, C. Roskill, M. Ryan and S. White. 2006. Fathers matter: Research findings on fathers and their involvement with social care services. London: Family rights group.

Autonen-Vaaraniemi, L. 2012. "Men's activism, moral reasoning and good fatherhood in post-divorce family context." NORMA-Nordic Journal for Masculinity Studies, 5 (1): 45-59.

Bangura Arvidsson, M. 2003. Irågasatta fader. Olika bilder av fader till socialutsatta barn [Fathers called into question - different images of fathers of socially vulnerable children]. $\mathrm{PhD}$ thesis. Lund: University of Lund.

Bayley, J., L. M. Wallace and K. Choudry. 2009. "Fathers and parenting programmes:

Barriers and best practice." Community Practioner 82 (4): 28-31. 
Björnberg, U. 1998. "Family orientation among men: A process of change in Sweden" In Women, work and the family in Europe, edited by E. Drew, R. Emerek and E. Mahon, 200207. New York, NY: Routledge.

Brown, L., M. Callahan, S. Strega, C. Walmsley and L. Dominelli. 2009. "Manufacturing ghost fathers: The paradox of father presence and absence in child welfare." Child and Family Social Work 14 (1): 25-34.

Brown, J. and J. Addington-Hall. 2008. "How people with motor neurone disease talk about living with their illness: a narrative study." Journal of Advanced Nursing 62 (2): 200-208.

Bäck-Wiklund, M. 2015. Book review: Fatherhood in the Nordic welfare states. Comparing care policies and practice. Nordic Social Work Research 5 (3): 270-274.

Call, J B. and K. Shafer. 2015. "Gendered Manifestations of Depression and Help Seeking Among Men." American Journal of Men's Health 31: 1-11.

Cameron, G., N. Coady and S. Hoy. 2014. "Perspectives on being a father from men involved with child welfare services." Child \& Family Social Work 19 (1): 14-23.

Coady, N., S. L. Hoy and G. Cameron. 2013. "Fathers' experiences with child welfare services." Child and Family Social Work 18: 275-284

Coltrane, S. and A. Behnke. 2013. "Fatherhood and family policies" In Handbook of father involvement: Multidisciplinary perspectives (2nd Edition), edited by N.J. Cabrera and C.S. Tamis-LeMonda, 419-437. New York, NY: Routledge.

Eerola, P. and J. Huttunen. 2011. "Metanarrative of the "new father" and narratives of young Finnish first-time fathers." Fathering 9: 211-231.

Eerola, P. 2014. "Nurturing, breadwinning and upbringing: Paternal responsibilities by Finnish men in early fatherhood." Community, Work \& Family 17: 308-324.

Elder G. H. Jr., M. K. Johnson and R. Crosnoe. 2003. The emergence and development of life course theory. In Handbook of the life course, edited by J.T. Mortimer, M.J. Shanahan, 3-19. Kluwer, New York.

Eriksson, M., M. Hester, S. Keskinen and K. Pringle (Eds.) 2005. Tackling men's violence in families. Nordic issues and dilemmas. Bristol: Policy Press.

Eriksson, M., L. Bruno and E. Näsman. 2013. Domestic violence, family law and school. Children's right to participation, protection and provision. London: Palgrave Macmillan.

Eydal, G. B. and T. Rostgaard (Eds.) 2015. Fatherhood in the Nordic welfare states. Comparing care policies and practice. Bristol: Policy Press.

Featherstone, B. 2004. "Fathers matter: A research review." Children \& Society 18 (4): 312319. 
Featherstone, B. 2013. Working with fathers: risk or resource? In Family troubles? Exploring changes and challenges in the family lives of children and young people, edited by J. Ribbens McCarthy, A. Hooper and V. Gillies, 315-326. Bristol: Policy Press.

Featherstone, B., K. Morris and S. White. 2014. "A marriage made in hell: Early intervention meets child protection.” British Journal of Social Work 44 (7): 1735-1749.

Federation of Mother and Child Homes and Shelters. 2014. FMCHS Yearbook 2014. Available online only in Finnish: http://www.ensijaturvakotienliitto.fi/liitto/vuosikertomus/

Flouri E. 2005. Fathering and child outcomes. West Sussex, England: John Wiley \& Sons Ltd.

Forsberg, H. 2005. "Talking feels like you wouldn't love Dad anymore" - Children's emotions, close relations and domestic violence. In Tackling men's violence in families. Nordic issues and dilemmas, edited by M. Eriksson, M. Hester, S. Keskinen and K. Pringle, 49-65. Bristol: Policy Press.

Forsberg, H. and T. Pösö. 2008. "Ambiguous position of the child in supervised meetings." Child \& Family Social Work 13 (1): 52-60.

Giddens, A. 1991. Modernity and self-identity: Self and society in the late modern age. Stanford University Press, Stanford, CA.

Goldscheider, F., E. Bernhardt and T. Lappegård. 2014. "Studies of men's involvement in the family - Part 1: Introduction.” Journal of Family Issues 35 (7): 879-890.

Hautanen, T. 2002. Keskustelua väkivaltaisen miehen isyydestä. [Discussions of violent men's fatherhood] Ensi- ja turvakotien liiton julkaisu 31, Helsinki: Ensi- ja turvakotien liitto.

Hautanen, T. 2005. Bypassing the relationship between fatherhood and violence in Finnish policy and research. In Tackling Men's Violence in Families: Nordic Issues and Dilemmas, edited by M. Eriksson, M. Hester, S. Keskinen and K. Pringle, 67-82. Bristol: Policy Press.

Hearn, J. and K. Pringle. 2006. "Men, masculinities and children: Some European perspectives." Critical Social Policy 26 (2): 365-389.

Hitlin, S. and G.H. Elder. 2007. "Time, self and the curiously abstract concept of agency." Sociological Theory 25 (2):170-191.

Hiitola, J. 2011. Vanhempien tekemä väkivalta huostaanottoasiakirjoissa. [Parental violence in custody documents]. Janus 19 (1), 4-19.

Hänninen, V. 2004. “A model of narrative circulation.” Narrative Inquiry 14 (1): 69-85.

Keskinen, S. 2005. Commitments and contradictions: linking violence, parenthood and professionalism. In Tackling Men's Violence in Families: Nordic Issues and Dilemmas, edited by M. Eriksson, M. Hester, S. Keskinen and K. Pringle, 31-48. Bristol, GB: Policy Press. 
Keskinen, S. 2005. Perheammattilaiset ja väkivaltatyön ristiriidat. Sukupuoli, valta ja kielelliset käytännöt [Family experts and conflicts in working with violence. Gender, power and linguistic practices]. $\mathrm{PhD}$ thesis. Tampere University Press: Tampere.

Keskinen, S. 2008. Näkyvissä ja näkymättömissä. Väkivalta perheammattilaisten työskentelyssä. [Violence in family practitioners' work]. In Paljastettu intiimi.

Sukupuolistuneen väkivallan dynamiikka, edited by S. Näre and S. Ronkainen, 311-343. Rovaniemi: Lapin yliopistokustannus.

LaRossa, R. 1997. The modernization of fatherhood. A social and political history. Chi cago: University of Chicago.

Lamb M. E. 2010. The role of the father in child development (5th ed.). Hoboken, NJ: John Wiley \& Sons.

Lee, S.J., J.L. Bellamy and N.B. Guterman. 2009. "Fathers, physical child abuse, and neglect: Advancing the knowledge base." Child Maltreatment 14 (3): 227-231.

Lundahl, B. W., D. Tollefson, H. Risser and M.C. Lovejoy. 2008. "A meta-analysis of father involvement in parent training." Research on Social Work Practice, 18: 97-106.

Marks, L. and R. Palkovitz. 2004. "American Fatherhood Types: The Good, the Bad, and the Uninterested." Fathering 2 (2), 113-129.

Maxwell, N., J. Scourfield, B. Featherstone, S. Holland and R. Tolman. 2012. "Engaging fathers in child welfare services: a narrative review of recent research evidence." Child \& Family Social Work 17 (2): 160-169.

Miettinen, A. and A. Rotkirch. 2012. Yhteistä aikaa etsimässä. Lapsiperheiden ajankäytön muutokset 2000-luvun Suomessa. [Looking forfamily time. Families' time use in the 2000s]. Väestöntutkimuslaitos Katsauksia E42. Helsinki: VL-Markkinointi.

McAdams, D. P., R. Josselson and A. Lieblich. 2001. Turns in the road: Narrative studies of lives in transition. Washington, DC: American Psychological Association.

McGill, B. S. 2014. "Navigating new norms of involved fatherhood: Employment, fathering attitudes, and father involvement." Journal of Family Issues 35 (8), 1089-1106.

Mykkänen, J. 2010. Isäksi tulon tarinat, tunteet ja toimijuus [Becoming a father - Types of narrative, emotions and agency]. $\mathrm{PhD}$ thesis. Jyväskylä: Jyväskylä studies in education, psychology and social research.

Nikander, P. 2008. "Working with transcripts and translated data." Qualitative Research in Psychology 5 (3): 225-231.

Nyqvist, L. 2001. Väkivaltainen parisuhde, asiakkuus ja muutos [Violent couple relationship, clientship and change]. Helsinki: Ensi- ja turvakotien liitto. 
Nyqvist, L. 2006. Miesten kriisikeskuksen loppuarviointi [The final evaluation of the men's crisis centre]. In Sanasta miestä. Kokemuksia miesten kriisityöstä [Man of his word. Experiences on crisis work with men], 86-171. Helsinki: Ensi- ja turvakotien liiton julkaisu 36.

Perälä, M., N. Halme and S. Nykänen. 2012. Lasten, nuorten ja perheiden palveluja yhteen sovittava johtaminen [Unifying services children, youth and families through management]. Helsinki: National Institute for Health and Welfare.

Pirskanen, H. 2011. Alkoholi, isyys ja valta. Ongelmajuovat isät miesten elämäntarinoissa [Alcohol, fatherhood and power. Problem-drinking fathers in their sons' life stories]. $\mathrm{PhD}$ thesis. Helsinki: Väestöliitto.

Pirskanen, H. 2015. "Sons of problem-drinking fathers: Narratives on the father-son relationship." Family Science 6 (1): 394-401.

Plummer, K. 2001. Documents in life 2. An invitation to a critical humanism. London, England: Sage.

Riessman, C. K. 2003. “Analysis of personal narratives.” In Inside interviewing. New lenses, new concerns, edited by J.A. Holstein and J.F. Gubrium, 331-343. Thousand Oaks, CA: Sage.

Scourfield, J. 2001. "Constructing men in child protection work." Men and Masculinities 4 (1): 70-89.

Shafer, K. and Wendt, D. 2015. "Men's Mental Health: A Call to Social Workers." Social Work 60 (2): 105-112.

Skårstad Storhauga, A. and K. Øien. 2011. "Fathers' encounters with the Child Welfare Service." Children and youth services review 34 (1): 296-303.

Somers, M. R. 1994. "The narrative constitution of identity: A relational and network approach." Theory and Society 23: 605-649.

Stanley, N., N. Graham-Kevan and R. Borthwick. 2012. "Fathers and Domestic Violence: Building Motivation for Change through Perpetrator Programmes." Child Abuse Review 21, (4): 264-274.

Storhaug, A. 2013. "Fathers' involvement in the child welfare service." Children and Youth Services Review 35 (10): 1751-1759.

Söderström, K. and F. Skårderud. 2013. "The good, the bad and the invisible father: A fenomenological study of fatherhood in men with substance use disorder." Fathering 11 (1): $31-51$.

Valkonen, J. and O. Lindfors. 2012. "Perinteinen maskuliinisuus miesten psykoterapian haasteena [Traditional masculinity as a challenge in psychotherapy]." Psykoterapia [Psychotherapy] 31: 330-347. 
Walmsley, C. and L. Tessier. 2015. Growing the Nordic Child: The Family and government as partners. Vancouver, BC: BC Council for Families.

Vogel, D. L., S.R. Heimerdinger-Edwards, J.H. Hammer and A. Hubbard. (2011). "Boys don't cry": Examination of the links between endorsement of masculine norms, selfstigma, and help-seeking attitudes for men from diverse backgrounds. Journal of Counseling Psychology 58: 365-382.

Vuori, J. 2001. Äidit, isät ja ammattilaiset. Sukupuoli, toisto ja muunnelmat asiantuntijoiden kirjoituksissa [Mothers, fathers and professionals. Gender, repetition and variety in expert texts]. PhD thesis. Tampere: Tampere University Press.

Ylikännö, M., H. Pääkkönen and M. Hakovirta. 2014. Time use of Finnish fathers -do institutions matter? In Fatherhood in the Nordic Welfare states. Comparing care policies and practice, edited by Guony Bjork Eydal and Tine Rostgaard, 103-120. 
Table 1. Juxtaposition of the narratives on support and agency.

\begin{tabular}{|l|l|l|l|l|}
\hline Narrative & The hero & The victim & The outsider & The fortunate \\
\hline Agency & Increasing & Decreasing & Stable (low) & $\begin{array}{l}\text { Stable } \\
\text { (moderate) }\end{array}$ \\
\hline Turning point(s) & $\begin{array}{l}\text { Stop substance } \\
\text { abuse }\end{array}$ & $\begin{array}{l}\text { When the parents' } \\
\text { felt they weren't } \\
\text { getting help with } \\
\text { the child } \\
\text { Mother's custody }\end{array}$ & $\begin{array}{l}\text { No specific } \\
\text { turning point }\end{array}$ & $\begin{array}{l}\text { No specific } \\
\text { turning point }\end{array}$ \\
\hline Main emotions & $\begin{array}{l}\text { Happiness, joy, } \\
\text { gratitude }\end{array}$ & $\begin{array}{l}\text { Disappointment, } \\
\text { pain, frustration, } \\
\text { feeling left alone }\end{array}$ & $\begin{array}{l}\text { Confusion, anger, } \\
\text { feeling } \\
\text { misunderstood }\end{array}$ & Pleased, neutral \\
\hline
\end{tabular}

